\title{
VALUASI EKONOMI HUTAN MANGROVE DI WILAYAH PESISIR DESA BOROKO KABUPATEN BOLAANG MONGONDOW UTARA PROVINSI SULAWESI UTARA
}

\author{
Stelah Kharina Hairunnisa, *Ardiyanto Maksimilianus Gai, dan Ida Soewarni \\ 1Perencanaan Wilayah dan Kota, Fakultas Teknik Sipil dan Perencanaan \\ Institut Teknologi Nasional Malang, *ardy 06pl@yahoo.co.id
}

\begin{tabular}{l} 
INFO ARTIKEL \\
\hline Riwayat Artikel: \\
Diterima:10-12-2017 \\
Disetujui:12-01-2018 \\
\hline
\end{tabular}

Kata Kunci:

Kata Kunci:

Mangrove

Valuasi

Ekonomi

Kerusakan

\begin{abstract}
ABSTRAK
Abstrak: Ekosistem hutan mangrove merupakan salah satu sumberdaya alam wilayah pesisir yang mempunyai fungsi dan manfaat sangat besar, antara lain secara fisik, biologis, dan ekonomi, dengan fungsi utama sebagai penyeimbang ekosistem dan penyedia berbagai kebutuhan hidup bagi manusia dan mahluk hidup lainnya. Kabupaten Bolaang Mongondow Utara merupakan salah satu wilayah pesisir yang memiliki ekosistem mangrove di mana ekosistem hutan mangrove yang ada memiliki luas 1.670,81 Ha luas keseluruhan, di mana Desa Boroko merupakan salah satu desa potensi hutan mangrove dengan jumlah luas persebaran sebesar $101 \mathrm{Ha}$, yang mengalami degradasi antara lain di beberapa titik telah dialih fungsikan untuk kegiatan perkebunan cengkeh, penebangan yang dijadikan kayu bakar, pembukaan jalan, tambak, dan permukiman dengan luas indikatif kerusakan sebesar $4 \mathrm{Ha}$. Penelitian ini bertujuan untuk mengetahui nilai ekonomi total hutan mangrove setelah dipetakan tingkat kerusakan dan memperhitungkan nilai pemulihannya. Dengan metode analisis yang digunakan antara lain analisis tingkat kerusakan menggunakan metode NDVI (Normalized Difference Vegetation Index), dan analisis nilai ekonomi total kawasan menggunakan metode analisis kuantitatif dengan pendekatan valuasi ekonomi. Hasil penelitian menunujukan nilai manfaat total hutan mangrove di Desa Boroko sebesar Rp.261.210.638.132.-/Tahun.
\end{abstract}

\begin{abstract}
The mangrove forest ecosystem is one of the coastal natural resources which have huge functions and benefit physically, biologically, and economically with the main function as the ecosystem balancer and natural resources for other living creatures. North Bolang Mongondow is a coastal area with mangrove ecosystem of 1,670.81 Ha in total. Boroko is one of villages with potential mangrove forest of $101 \mathrm{Ha}$ which has degraded due to function shifting at some points to be clove plantation, logging, roads, ponds, and settlement with indicative area of damage of $4 \mathrm{Ha}$. This research aims to understand the total economic value of mangrove forest after being mapped based on the damage level and its recovery cost by employing NDVI (Normalized Difference Vegetation Index) to analyze the damage level and quantitative analysis with economic value approach to analyze the total economic value of the area. The results showed the total benefit of mangrove forest at Boroko Village was IDR 261,210,638,132/year.
\end{abstract}

\section{A. LATAR BELAKANG}

Wilayah pesisir dan lautan indonesia yang kaya dan beragam sumber daya alamnya telah dimanfaatkan oleh bangsa indonesia sebagai salah satu sumber bahan makanan utama, khususnya protein hewani, sejak berabad-abad lamanya. Sementara itu kekayaan hidrokarbon dan mineral lainnya yang terdapat di wilayah ini juga telah dimanfaatkan untuk menunjang pembangunan ekonomi nasional. Selain menyediakan berbagai sum ber daya tersebut, wilayah pesisir dan lautan indonesia memilki berbagai fungsi lain, seperti transportasi dan pelabuhan, kawasan industri, agribisnis dan agroindustri, rekreasi dan pariwisata, serta kawasan Artikel penulisan harus dalam format dua kolom, permukiman dan tempat pembuangan limbah (Soraya, 2012) [1].
Ekosistem hutan mangrove merupakan salah satu sumberdaya alam wilayah pesisir yang mempunyai fungsi dan manfaat sangat besar, fungsi dan manfaat hutan mangrove dibagi menjadi tiga golongan besar secara fisik, biologis, dan ekonomi. Fungsi utama sebagai penyeimbang ekosistem dan penyedia berbagai kebutuhan hidup bagi manusia dan mahluk hidup lainnya. Sumberdaya hutan mangrove sebagai penyedia sumberdaya kayu juga sebagai tempat pemijahan (Spawning ground), daerah asuhan (nursery ground), dan juga sebagai daerah untuk mencari makan (feeding ground) bagi ikan dan biota laut lainnya, juga berfungsi untuk menahan gelombang laut dan intrusi air laut kearah darat (Anugra, 2014) [3]. Menurut Hanifa2013) nilai ekonomi hutan mangrove dapat diklasifikasikan berdasarkan manfaatnya sebagai nilai ekonomi total. Nilai ekonomi ini dibagi menjadi dua bagian yaitu nilai 
guna (Use Value) dan nilai non-guna (non-use value). Dimana nilai guna ini dibagi menjadi nilai guna langsung (direct use value), nilai guna tidak langsung (indirect use value). Sedangkan nilai non guna terdiri dari nilai keberadaan (exsistence values) dan nilai pilihan (option value) ${ }_{[4]}$.

Besarnya manfaat yang ada pada ekosistem hutan mangrove, memberikan konsekuensi bagi ekosistem hutan mangrove itu sendiri, yaitu dengan semakin tingginya tingkat ekploitasi terhadap lingkungan yang tidak jarang berakhir pada degredasi lingkungan yang cukup parah (Setiawan, 2013 dalam Anugra, 2014). Pemanfaatan yang berlebihan telah mengakibatkan ekosistem mangrove mengalami kerusakan yang memprihatinkan sehingga mengancam kelestariannya [3].

Sejak tahun 1980-an, mulai dikembangkan metode untuk memperoleh nilai ekonomi yang dilakukan melalui estimasi biaya (cost) maupun manfaat (benefit) dari lingkungan termasuk dampaknya yang mungkin terjadi (Djakapermana,2005). Nilai lingkungan tidak hanya tergantung pada nilai pasar pemanfaatan langsung saja, melainkan juga tergantung pada seluruh fungsi sumberdaya lain yang menghasilkan nilai yang setinggi-tingginya. Konsep ini dikenal dengan nilai ekonomi total (Total Economic Valuation/TEV). Model TEV (Total Economic Valuation) adalah salah satu model untuk menghitung manfaat ekonomi dengan memperhatikan aspek pelestarian lingkungan hidup (Djakapermana, 2005)

Kabupaten Bolaang Mongondow Utara merupakan salah satu wilayah pesisir yang memiliki ekosistem mangrove di mana ekosistem hutan mangrove yang ada memiliki luas $1.670,81$ Ha luas keseluruhan. Wilayah Pesisir Utara Kabupaten Bolaang Mongondow Utara memiliki panjang garis pantai $602 \mathrm{~km}$ yang membentang dari Poigar yang berbatasan dengan kabupaten Minahasa Selatan hingga ke Sangtombolang yang berbatasan dengan Kabupaten Bolaang Mongondow Utara. Menurut Dinas Kehutanan Kabupaten Bolaangmongondow Utara data potensi jenis mangrove tahun 2015 yang tersebar di Kabupaten Bolaangmongondow Utara yaitu Aviceniasp (Api-api), Brugueieragymnorrizha

Lindur) Xylocarpusgranatum (Nyirih) SonneratiaSpp ( Pidada ) Nypafruticans ( Nipa).Berdasarkan Data Dinas Kehutanan Kabupten Bolaangmongondow Utara Tahun 2015 tentang Kerusakan Kawasan Hutan Lindung, Kabupaten Bolaangmogondow Utara memiliki Kondisi hutan mangrove dengan tekanan eksploitasi yang dapat mengarah kepada kerusakan lingkungan dan sumberdaya alam pesisir bila tidak dikelola dengan baik, mempunyai dinamika sedimentasi dan abrasi yang tinggi, dengan luas indikatif kerusakan sebesar 136.625 Ha terdiri dari 14 Desa yang memiliki sebaran hutan mangrove [6]. Di samping itu, jalan lintas utara menuju
Kabupaten Bolaang Mongondow Utara berada di tepidan dekat pantai pesisir utara.

Desa Boroko merupakan salah satu desa yang berada di Kabupaten Bolaangmongondow utara berlokasi di kecamatan kaidipang dengan luas wilayah sebesar 408,05 km². Desa boroko juga memiliki potensi persebaran hutan mangrove dengan jumlah luas persebaran sebesar 101Ha. Dari segi ekonomi manfaat yang diterima dari hutan mangrove oleh masyarakat pesisir Desa Boroko yaitu hasil hutan untuk produksi kayu bakar, selain fungsi dan manfaat yang dirasakan masyarakat,hutan mangrove Desa Boroko memiliki permasalahan akibat pemanfaatan hutan mangrove. Menurut Dinas Kehutanan Kabupaten Bolaangmongondow Utara Data Perambahan Kawasan Hutan Lindung tahun 2015 di beberapa titik telah dialih fungsikan untuk kegiatan perkebunan cengkeh, penebangan yang dijadikan kayu bakar, pembukaan jalan, tambak, dan permukiman yang mengalami kerusakan dengan tipe kerusakan untuk penggunaan pembukaan lahan yang dijadikan lahan Untuk permukiman, perdagangan dan jasa yang ditandai dengan kerusakan hutan mangrove Desa Boroko dengan luas indikatif kerusakan sebesar $4 \mathrm{Ha}$ [6].

Berdasarkan pada uraian uraian rumusan masalah, maka tujuan dari penelitian ini adalah untuk mengetahui nilai ekonomi total (Total Economic Valuation/TEV) di Desa Boroko Kecamatan Kaidipang Kabupaten Bolaangmongondow Utara. setelah dipetakan tingkat kerusakan dan memperhitungkan nilai pemulihannya.

\section{B. METODE PENELITIAN}

Metode pengambilan sampel dalam penelitian ini menggunakan metode Purposive Sampling.Dengan total sampel 76 responden, sampel nelayan sebanyak 50 responden, dinas kehutanan sebanyak 7 responden, dinas perikanan 7 responden, dan masyarakat 7 responden.

Analisis data untuk tingkat kerusakan ekosistem hutan mangrove menggunakan pendekatan analisis vegetasi mangrove untuk mendapatkan kerapatan jenis dan penutupan, tetapi sebelumnya untuk mengetahui titik-titik mana yang mengalami penurunan menggunakan metode NDVI (Normalized Difference Vegetation Index). Indeks vegetasi adalah salah satu parameter yang digunakan untuk menganalisa keadaan vegetasi dari suatu wilayah. Indeks vegetasi merupakan metode transformasi citra berbasis data spektral yang banyak dimanfaatkan untuk pengamatan tumbuhan. Untuk mengetahui tingkat kerapatan vegetasi dapat dikaji melalui penggunaan teknologi yaitu teknologi penginderaan jauh dan aplikasi ENVI setelah mendapatkan tingkat kerapatan mangrove lalu menentukan jumlah lokasi amatan dengan metode Proporsional Cluster Random Sampling lalu jumlah titik lokasi amatan dipetakan menggunaan sistem informasi 
geografis (Puspita, 2015) [5]. Kemudian dihitung total nilai ekonomi kawasan dengan menggunakan rumus:

$\mathrm{NET}=\mathrm{ML}+\mathrm{MTL}+\mathrm{MP}+\mathrm{MK}$

Dimana :

$\begin{array}{ll}\text { NET } & =\text { Nilai ekonomi total } \\ \text { ML } & =\text { Nilai manfaat langsung } \\ \text { MTL } & =\text { Nilai manfaat tidak langsung } \\ \text { MP } & =\text { Nilai manfaat pilihan } \\ \text { MK } & =\text { Nilai manfaat keberadaan }\end{array}$

\section{HASIL DAN PEMBAHASAN}

\section{Potensi Ekosistem Mangrove Desa Boroko}

Analisa potensi mangrove Pertama, Nilai Manfaat Langsung untuk kondisi eksisting, nilai manfaat langsung yang mengalami kerusakan, nilai manfaat langsung perbaikan, nilai manfaat langsung keseluruhan. Kedua, Nilai Manfaat Tidak Langsung yaitu manfaat fisik dan manfaat biologi. Ketiga, Nilai Manfaat Pilihan. Keempat, Nilai Manfaat Keberadaan.

Nilai Manfaat Langsung kondisi eksisting dengan

nilai manfaat pertahunnya sebesar Rp.3.692.055.00o dari kegiatan eksisting pengambilan kayu bakar 4 Rp.1.958.895.00o/Tahun, perikanan Rp.1.733.160.00o/Tahun. Untuk nilai manfaat langsung yang mengalami kerusakan sebesar Rp.146.220.000, terjadi kerugian sebesar 146 juta pertahun dari nilai kerusakan terhadap manfaat langsung eksisting dengan jumlah pohon yang rusak sebanyak 288.000 pohon dalam 4 ha kawasan yang mengalami kerusakan. Lalu untuk nilai manfaat langsung yang dalam perbaikan terhadap kerugian yang disebabkan kerusakan untuk nilai ekonomi perbaikan terhadap kerusakan sebesar Rp.179.867.520.000 dan nilai keuntungan setelah perbaikan sebesar Rp.254.812.320.000 dengan jumlah pohon perbaikan sebanyak $\mathrm{Rp} 696.000$ pohon kemudian, nilai ekonomi yang terkandung dalam satu pohon mangrove sebesar Rp.624.540 /Pohon dengan bentuk produk olahan yaitu sebagai bahan obat-obatan tanpa merusak ekosistem mangrove. Lalu, untuk nilai manfaat keseluruhan yang merupakan potensi mangrove secara keseluruhan dengan jumlah pohon di lokasi studi sebanyak 10.380.000 pohon dengan 3 kategori umur mangrove semaian (4 bulan-3tahun), anakan (3-5 tahun), dan pohon besar (5-10 tahun).

Nilai ekonomi keseluruhan dapat ditinjau dalam 10 tahun proyeksi. . Dalam menghasilkan nilai ekonomi mangrove tidak semata-mata dilakukan setiap saat sebab hutan mangrove perlu menjaga fungsi ekologisnya sebagai salah satu kawasan lindung khususnya wilayah pesisir. hutan mangrove memiliki masa produksi dalam 10 tahun kedepan yaitu pada tahun ke-1, ke-5, ke-6 dan ke-10. Hal ini mengingat siklus pertumbuhan pohon mangrove yang terjadi setiap 5 tahun sekali agar dapat diproduksi secara maksimal.
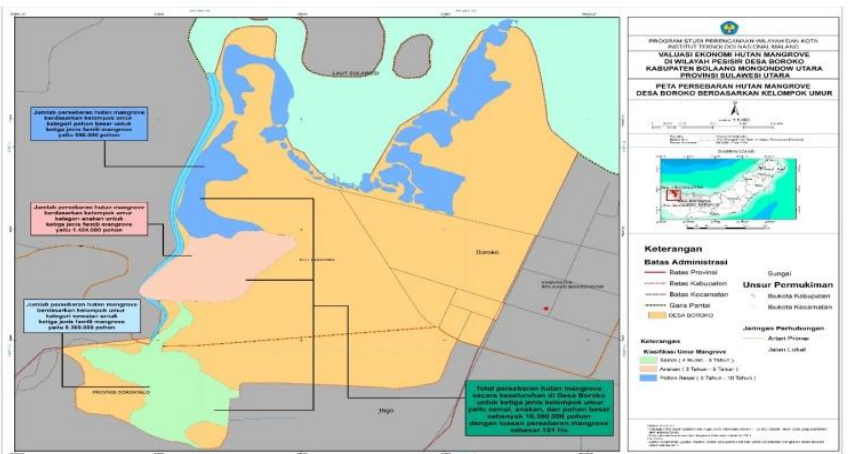

Gambar 1. Peta Persebaran Mangrove Berdasarkan Kelompok Umur

Tabel 1.

Nilai manfaat langsung

\begin{tabular}{|l|l|c|}
\hline No & \multicolumn{1}{|c|}{ Jenis Manfaat Langsung } & $\begin{array}{c}\text { Nilai Manfaat } \\
\text { Langsung } \\
\text { (Rp) }\end{array}$ \\
\hline 1 & Manfaat Langsung Eksisting & 3.692 .055 .000 \\
\hline 2 & $\begin{array}{l}\text { Manfaat Langsung yang Mengalami } \\
\text { Kerusakan }\end{array}$ & 146.220 .000 \\
\hline 3 & Manfaat Langsung dalam Perbaikan & 254.812 .320 .000 \\
\hline 4 & Manfaat Langsung Keseluruhan & 6110499360000 \\
\hline
\end{tabular}

Nilai Manfaat Tidak Langsung dari hutan mangrove Desa Boroko terdiri atas manfaat fisik dan biologis. Manfaat fisik ini merupakan manfaat hutan mangrove sebagai peredam gelombang laut, pelindung tebing sungai, penghasil oksigen, penyerab karbon, , penangkar buaya yang diestimasi dengan pendekatan Replacement cost atau biaya pengganti mengacu dengan cara perhitungan pada Buku Penilaian Ekonomi Ekosistem Hutan Mangrove \& Aplikasinya dalam Perencanaan Wilayah Pesisir oleh Nuddin Harahab. Nilai Manfaat Tidak Langsung Desa Boroko Sebesar Rp.257.478.444.078/Tahun. Manfaat Fisik sebagai penahan abrasi dan gelombang air laut sebesar Rp.9.543.307.087/Tahun, sebagai pelindung tebing sungai Rp.4.431.496.063,-/Tahun, sebagai penahan instrusi air laut Rp.1.277.500/Tahun, sebagai penyerab karbon Rp.5.252.00o.ooo/Tahun, sebagai penghasil oksigen Rp.4.283.915/Tahun, sebagai penangkar buaya Rp.111.504.000.00o/Tahun. Manfaat biologi sebagai penyedia pakan Rp.126.192.507.750/Tahun, sebagai penyedia unsur hara Rp.246.763/Tahun.

Tabel 2.

Nilai manfaat tidak langsung

\begin{tabular}{|l|l|l|}
\hline No & \multicolumn{1}{|c|}{$\begin{array}{c}\text { Manfaat } \\
\text { Langsung }\end{array}$} & \multicolumn{1}{c|}{ Nilai(Rp) } \\
\hline 1 & $\begin{array}{l}\text { Penahan Abrasi dan } \\
\text { Gelombang Air Laut }\end{array}$ & $9.543 .307 .087 /$ Tahun \\
\hline 2 & $\begin{array}{l}\text { Pelindung Tebing } \\
\text { Sungai }\end{array}$ & $4.431 .496 .063 /$ Tahun \\
\hline 3 & $\begin{array}{l}\text { Penahan Instrusi Air } \\
\text { Laut }\end{array}$ & $1.277 .500 /$ Tahun \\
\hline 4 & Penyerab Karbon & $5.252 .000 .000 /$ Tahun \\
\hline 5 & Penghasil Oksigen & $4.283 .915 /$ Tahun \\
\hline 6 & Penangkar Buaya & $111.504 .000 .000 /$ Tahun \\
\hline 7 & Penyedia Pakan & $126.192 .507 .750 /$ Tahun \\
\hline 8 & $\begin{array}{l}\text { Penyedia Unsur } \\
\text { Hara }\end{array}$ & $\mathbf{2 4 6 . 7 6 / T a h u n ~}$ \\
\hline Jumlah & $\mathbf{2 5 7 . 4 7 8 . 4 4 4 . 0 7 8 / T a h u n ~}$ \\
\hline
\end{tabular}


Nilai manfaat pilihan Desa Boroko dihitung dari manfaat keanekaragaman hayati (biodiversity) dianalisis menggunakan metode Benafit Transfer. Mengacu pada manfaat tidak langsung hutan mangrove dengan nilai standar biodiversity sekitar US $\$ 15$ per hektare per tahun (Ruitebeek, 1992). Dengan luasan lahan hutan mangrove di kawasan penelitian berkisar $101 \mathrm{Ha}$, maka dapat dihitung manfaat pilihan yang diperoleh dari perkalian nilai standar biodiversity sebesar US $\$ 15 / \mathrm{Ha} /$ tahun dengan nilai tukar Rupiah saat ini mencapai $\mathrm{Rp}$. 13.00o,- dikalikan dengan luas hutan mangrove di kawasan penelitian. Maka diperoleh nilai manfaat pilihan sebesar Rp.195.00o/Ha/tahun dan Total Manfaat Pilihan hutan mangrove Desa Boroko sebesar Rp. 19.695.00o/tahun.

Nilai Manfaat Keberadaan Desa Boroko dihitung menggunakan pendekatan CVM (Contigent Valuation Method). Nilai rataan WTP (Wilingness To Pay) yang diperoleh dari 76 responden sebuesar Rp.47.434/ha/tahun dikalikan dengan jumlah KK Desa Boroko $431 \mathrm{KK}$, sehingga diperoleh nilai perhitungan Rp.20.444.054/Tahun.

\section{Tingkat Kerusakan Ekosistem Mangrove Desa Boroko}

Mengitung tingkat kerusakan dengan analisis vegetasi mangrove mengacu pada perhitungan oleh Amran Saru dalam Buku Potensi Ekologis dan Pengelolaan Ekosistem Mangrove di Wilayah Pesisir. Berdasarkan 3 kategori umur yaitu vegetasi kategori pohon, vegetasi kategori anakan, vegetasi kategori pancang.

Vegetasi Kategori Pohon nilai kerapatan realtif yang tertinggi ada pada mangrove jenis Avichenia spp , yaitu berkisar antara $55,19 \%$ terendah pada jenis Rhizopora berkisar antara $21,97 \%$, sementara untuk nilai frekuensi relative tertinggi adalah Avichenia spp dengan nilai kisaran 36,58 \%. Dan frekunesi terendag adalah jenis Nypafrutican dengan nilai kisaran 1,53\%.

Vegetasi Kategori Anakan Hasil analisis kategori pancang yang memiliki nilai kerapatan relatif tertinggi kategori pancang yaitu pada jenisRhizopora yang memiliki nilai $46,91 \%$ dan terendah adalah jenis Nypafrutican dengan nilai 19,21 \% selanjtuna untuk nilai frekuensi tertinggi kategori pancang adalah jenis Rhizopora dengan nilai 35,94 \% dan nilai frekuensi terendah adalah spesies Nypafrutican 21,56\%.

Vegetasi Kategori Semaian hasil analisis di peroleh nilai kerapatan relative tertinggi pada spesies Rhizopora dengan kisaran nilai 55,86 \% selanjutnya kerapatan relative yang terendah adalah spesies Nypafrutican dengan kisaran nilai 17,81\% kemudian untuk nilai frekuensi relative yang tertinggi adalah jenis Rhizopora dengan kisaran nilai $78,43 \%$ sedangkan terendah adalah spesies Nypafrutican dengan kisaran nilai $21,56 \%$.
Tabel 3.

Kriteria Baku Kerusakan Mangrove

\begin{tabular}{|l|c|c|c|}
\hline \multicolumn{2}{|c|}{ Kriteria } & $\begin{array}{c}\text { Penutupan } \\
\text { (\%) }\end{array}$ & $\begin{array}{c}\text { Kerapatan } \\
\text { Pohon } \\
\text { (pohon/Ha) }\end{array}$ \\
\hline \multirow{2}{*}{ Baik } & $\begin{array}{c}\text { Sangat } \\
\text { Padat }\end{array}$ & $>75$ & $>1500$ \\
\cline { 2 - 4 } & Sedang & $>50-<75$ & $>1000->1500$ \\
\hline Rusak & Jarang & $<50$ & $<1000$ \\
\hline
\end{tabular}

Parameter penutupan mangrove dilakukan menggunakan metode basal coverage yang didasarkan oleh luas batang pohon, untuk analisis data tingkat kerusakan pada 3 stasiun pengamatan dengan mengetahui lingkar batang pohon pengamatan dengan hasil pengamatan sebagai berikut :

Tabel 4.

Nilai Penutupan Mangrove Desa Boroko

\begin{tabular}{|l|c|c|c|c|}
\hline \multirow{2}{*}{ Lokasi } & \multicolumn{3}{|c|}{ Penutupan } & \multirow{2}{*}{ Standar } \\
\cline { 2 - 4 } $\mathbf{1}$ & Pohon & Pancang & Semaian & \\
\hline $\begin{array}{l}\text { Stasiun } \\
\mathbf{2}\end{array}$ & 61 & 107 & 0,19 & $\begin{array}{c}\text { Rusak } \\
\text { Ringan } \\
>75\end{array}$ \\
\hline $\begin{array}{l}\text { Stasiun } \\
\mathbf{3}\end{array}$ & 50 & 20 & 0,02 & $\begin{array}{c}\text { Rusak } \\
\text { Sedang } \\
>50-<75\end{array}$ \\
\hline
\end{tabular}

Berdasarkan hasil pengukuran vegetasi di lapangan menunjukan bahwa 3 stasiun pengamatan tergolong rusak ringan, rusak sedang dan rusak berat. Pada stasiun 1 dengan nilai penutupan mangrove 61 dengan kategori rusak ringan yang dalam artian terrdapat beberapa kondisi kurang baik dari mangrove tetapi belum banyak mendominasi pada stasiun 1 , dan pada stasiun pengamatan 2 dengan nilai penutupan 50 dalam kategori rusak sedang jumlah kerusakan dengan mangorve secara keseluruhan masih dalam kondisi yang sama, untuk stasiun 3 dengan kategori rusak berat yang

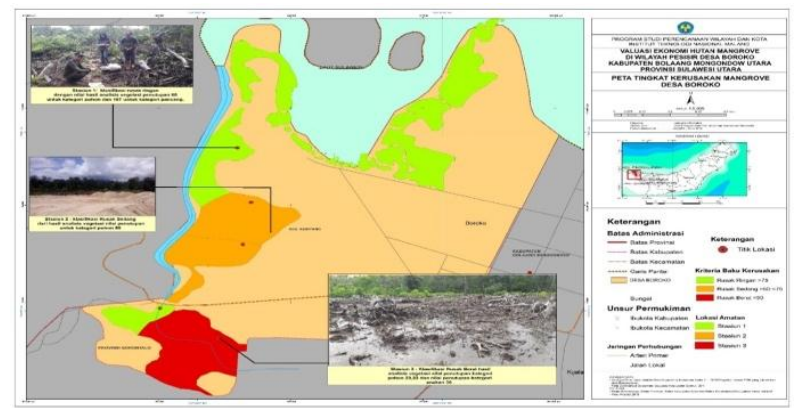

artinya keruskan banyak ditemukan di areal staisun pengamatan 3.

Peta 2. Tingkat Kerusakan Mangrove Desa Boroko

\section{Nilai Ekonomi Total Hutan Mangrove Desa Boroko}

Nilai ekonomi total hutan mangrove dapat diketahui setelah menjumlahkan hasil dari penilaian manfaat hutan mangrove secara keseluruhan. Maka yang memberikan proporsi paling tinggi terdapat pada nilai 
ekonomi total ekosistem hutan mangrove di Desa Boroko

adalah manfaat tidak langsung dengan nilai sebesar Rp.257.478.444.078,-/tahun atau 97.3\%, kemudian manfaat langsung sebesar Rp.3.692.055.000,/tahun atau 2,46 \%, dan manfaat keberadaan sebesar Rp.20.444.054,-/tahun atau 0,1\%, sedangkan manfaat pilihan memberikan nilai sebesar Rp.19.695.00o,/tahun atau hanya $0,1 \%$ dari total nilai manfaat.

Tabel 5.

Nilai ekonomi total hutan mangrove desa boroko

\begin{tabular}{|c|l|r|r|}
\hline No & Kategori Manfaat & \multicolumn{1}{|c|}{$\begin{array}{c}\text { Nilai Manfaat } \\
\text { Rp/Tahun }\end{array}$} & (\%) \\
\hline 1 & Manfaat Langsung & 3.692 .055 .000 & 2,46 \\
\hline 2 & $\begin{array}{l}\text { Manfaat Tidak } \\
\text { Langsung }\end{array}$ & 257.478 .444 .078 & 97.3 \\
\hline 3 & Manfaat Pilihan & 19.695 .000 & 0,1 \\
\hline 4 & Manfaat Keberadaan & 20.444 .054 & 0,1 \\
\hline \multicolumn{2}{|c|}{ Nilai Manfaat Total } & 261.210 .638 .132 & $\mathbf{1 0 0}$ \\
\hline
\end{tabular}

Nilai manfaat tidak langsung yang memberikan proporsi lebih besar dibandingkan nilai manfaat lain, karena manfaat fisik berupa penahan abrasi, penahan instrusi air laut, penyerap karbon, penghasil oksigen serta manfaat biologi sebagai penyedia pakan udang dan kepiting lalu juga sebagai penjaga kestabilan siklus makanan.

Nilai ekonomi total ekosistem hutan mangrove di Desa Boroko mengindikasikan bahwa sumberdaya alam dan lingkungan memerlukan penghargaan yang lebih tinggi dan memang menjadi dasar informasi secara kuantitatif untuk menentukan berbagai pilihan kebijakan, baik kebijakan fisikal maupun moneter,penyesuaian structural dan upaya stabilisasi, karena mempunyai dampak terhadap sector yang bergantung pada sumberdaya alam. Penilaian dampak pembangunan terhadap sumberdaya alam dan lingkungan merupakan suatu langkah menuju pengelolaan sumberdaya alam secara berkelanjutan.

\section{SIMPULAN DAN SARAN}

Berdasarkan hasil penelitian yang diuraikan, maka diperoleh kesimpulan sebagai berikut:

\section{Potensi Ekosistem Hutan Mangrove}

Manfaat langsung potensi kayu bakar sebesar Rp.1.958.895.000,-/tahun, dan bagian perikanan untuk udang windu dan kepiting bakau total nilai manfaat sebesar Rp.1.733.160.000,-/tahun. Jadi untuk nilai manfaat langsung yang diperoleh pertahunnya sebesar Rp.3.692.055.000,-/tahun. Dan untuk manfaat tidak langsung yaitu manfaat fisik sebagai penahan abrasi, penahan instrusi air laut, penyerap karbon, penghasil oksigen dan manfaat biologi sebagai penyedia pakan dan penjaga kestabilan siklus makanan dengan nilai manfaat sebesar Rp.257.478.444.078,-/,-/tahun. Lalu untuk nilai manfaat pilihan dengan nilai sebesar Rp.19.695.00o/Tahun, sedangkan untuk nilai manfaat keberadaan sebesar Rp.20.444.054 /ha/tahun.
2. Tingkat Kerusakan Hutan Mangrove

kategori yaitu semaian,anakan/pancang, dan pohon.

- Untuk analisis vegetasi mangrove kategori pohon nilai kerapatan relative tertinggi pada manrove jenis Avichenia spp sebesar55,19\% dan terendah pada jenis Rhizoporasebesar 21,97\%.

- Untuk analisis vegetasi mangrove kategori anakan/pancang nilai kerapatan relatif tertinggi kategori pancang yaitu pada jenisRhizopora sebesar46,91 \%dan terendah adalah jenis Nypafrutican dengan nilai 19,21\% .

- Untuk analisis vegetasi mangrove kategori semaian nilai kerapatan relative tertinggi pada spesies Rhizopora sebesar55,86 \% dan yang terendah adalah spesies Nypafrutican sebesar $17,81 \%$.

Pada stasiun 1 dengan nilai penutupan mangrove 61 dengan kategori rusak ringan yang dalam artian terrdapat beberapa kondisi kurang baik dari mangrove tetapi belum banyak mendominasi pada stasiun 1 , dan pada stasiun pengamatan 2 dengan nilai penutupan 50 dalam kategori rusak sedang jumlah kerusakan dengan mangorve secara keseluruhan masih dalam kondisi yang sama, untuk stasiun 3 dengan kategori rusak berat yang artinya keruskan banyak ditemukan di areal staisun pengamatan.

3. Nilai Ekonomi Total Hutan Mangrove Desa Boroko

Berdasarkan hasil analisis ekosistem mangrove menunjukan bahwa yang memberikan proporsi paling tinggi terhadap nilai ekonomi total ekosistem hutan mangrove adalah manfaat tidak langsung sebesar 97,3\% kemudian manfaat langsung sebesar Rp.2,46\%, dan manfaat pilihan sebesar $0,1 \%$, sedangkan manfaat keberadaan memberikan nilai sebesar $0,1 \%$ dari total nilai manfaat hutan mangrove Desa Boroko sebesar Rp.261.210.638.132,-/tahun.

\section{REKOMENDASI}

Berdasarkan simpulan penelitian, rekomendasi yang dapat sampaikan kepada stakeholder dalam upaya menentukan konsep pengelolaan yang sesuai dengan mempertimbangkan kondisi eksositem yang diawali dengan mengetahui seberapa besar total nilai ekonomi dari hutan mangrove yang menjamin keberlajutan sumberdaya dengan melakukan penilaian terhadap ekosistem mangrove adalah,

1. Diperlukan program peningkatan pendapatan nelayan melalui mata pencaharian alternatif, sehingga masyarakat tidak menggantungkan hidupnya pada ekosistem mangrove yang pada akhirnya mendorong mereka melakukan kegiatan yang dapat merusak kelestarian mangrove mengingat tingginya nilai eksistensi dari mangrove tersebut. 
2. Diperlukan konsep penanganan/perbaikan terhadap kondisi ekosistem mangrove yang mengalami penurunan kondisi serta kualitas berdasarkan tingkat kerusakannya.

3. Diperlukannya rehabilitasi mangrove karena kerusakan yang dialami oleh sumberdaya wilayah pesisir untuk menjaga kelestarian hutan manrove bias melalui beerapa tahapan sebagai berikut :

a. Pembuatan Bedeng

Pembuatan bedeng persemaian mangrove.

Lokasi bedeng, dipilih yang berdekatan dengan lokasi penanaman mangrove. Hal ini, bertujuan untuk mempermudah distribusi bibit mangrove pada saat penanaman

b.Pembangunan APO

Hal ini dilakukan untuk melindungi bibit-bibit mangrove yang telah ditanam di lokasi program rehabilitasi mangrove.

\section{UCAPAN TERIMA KASH}

Penulis menyampaikan rasa terima kasih yang sebesarbesarnya dan penghargaan setinggi-tingginya kepada Program Studi Perencanaan Wilayah dan Kota yang telah menjadi tempat kami ditempa menjadi manusia yang berkualitas. Terima kasih juga untuk bapak Dr. Ir. Ibnu Sasongko dan Ibu Annisa H., ST., M.Sc yang juga sudah membantu kami dalam menyelesaikan penelitian ini.

\section{DAFTAR RUJUKAN}

\section{Jurnal}

[1] Dida, Soraya, "Perubahan Garis Pantai Akibat Kerusakan Hutan Mangrove Di Kecamatan Blanakan dan Kecamatan Legonkulon,Kabupaten Subang,2012", Perikanan dan Kelautan, Vol 3, No. 4, h. 355-364, 2012.

[2] Jaka, Ruchyat, "Perhitungan Nilai Ekonomi Total Dalam Rangka Pemanfaatan Ruang Wilayah Pulau Kalimantan,2005”, Perencanaan Wilayah dan Kota, Vol 16, No. 3, h. 57-75, 2005.

[3] Fuad, Anugra, "Tingkat Kerusakan Hutan Mangrove Pantai di Desa Malakosa Kecamatan Balinggi Kabupaten Parigi Moutong,2014" Ilmu Perikanan dan Kelautan, Vol 2, No. 1, 2014.

[4] Hanifa, Aurora, "Kajian Valuasi Ekonomi Hutan Mangrove di Desa Pasar Banggi, Kecamatan Rembang, Kabupaten Rembang,2013" Journal of Marine Research, Vol 2, No. 2, h. 140-148, 2013.

[5] Sari, Puspita," Detection of Mangrove Distribution in Pongok Island. 2The $2^{\text {nd }}$ International Symposium on LAPAN-IPB Satellite for FOOD Security and Environmental Monitoring,2015" LISAT-FSEM. Procedia Environmental Science, Vol 33, h. 253-257, 2015.

\section{Artikel/Modul/Diktat}

[6] Lingkungan Hidup Daerah, Status Lingkungan Hidup Daerah Kabupaten Bolaang Mongondow Utara Provinsi Sulawesi Utara, Dinas Lingkungan Hidup SULUT, Bolmut, 2015.

\section{PROFIL PENULIS UTAMA}

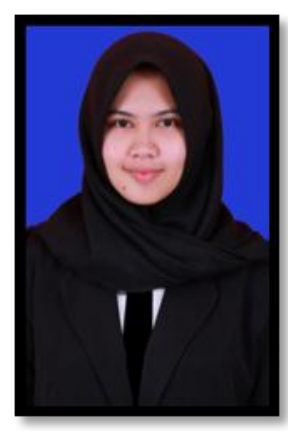

Stelah Kharina Hairunnisa, ST dilahirkan di Palu Sulawesi Tengah, pada tanggal 24 September 1995. Anak Tunggal pasangan Bapak Muh.Tahir dan Ibu Sri Sukesi Mokodompis. la memulai pendidikan sekolah dasar di SDN 3 Palu tamat tahun 2007, kemudian melanjutkan ke sekolah Lanjutan Tingkat Pertama Negeri 02 Palu tamat tahun 2010. Pendidikan Sekolah Menengah Atas Negeri 01 Palu tamat tahun 2013. Pendidikan berikutnya ditempuh di Institut Teknologi Nasional (ITN) Malang, Fakultas Teknik Sipil dan Perencanaan Program Studi Perencanaan Wilayah dan Kota. 